\title{
Pemanfaatan Limbah Plastik Jenis PET (Poly Ethylene Terephthalate) Pada Pembuatan Beton Mutu Rendah Di Kota Palangka Raya
}

\author{
Kamaliah $^{1^{*}}$, Noviyanthy Handayani ${ }^{2}$ \\ ${ }^{1}$ Program Studi Teknik Lingkungan Fakultas Teknik Universitas Muhammadiyah Palangkaraya \\ ${ }^{2}$ Program Studi Teknik Sipil Fakultas Teknik Universitas Muhammadiyah Palangkaraya \\ Surel: *kamaliahchua@gmail.ac.id
}

\begin{abstract}
ABSTRAK
Penelitian tentang pemanfaatan limbah plastik jenis PET (Poly Ethylene Terephthalate) terutama dalam bidang teknik sipil belum begitu banyak dilakukan di Palangka Raya. Padahal setiap hari di Palangka Raya, jenis limbah plastik ini cukup besar jumlahnya. Pengelolaan limbah jenis ini pun masih belum maksimal, sehingga sampah jenis ini dapat mengganggu lingkungan di Palangka Raya. Oleh karena itu perlu dilakukan penelitian agar limbah plastik tersebut dapat digunakan sebagai bahan bangunan teknik sipil dalam hal ini sebagai bahan campuran beton mutu rendah. Penelitian ini bertujuan untuk mengetahui apakah limbah plastik jenis PET (Poly Ethylene Terephthalate) dapat digunakan sebagai bahan campuran untuk beton mutu rendah di Kota Palangka Raya dan sejauh mana pengaruhnya terhadap kuat tekan beton mutu rendah. Penelitian ini menggunakan metode percobaan di laboratorium. Mutu beton yang direncanakan adalah K 225 yang termasuk klasifikasi beton mutu rendah. Pengujian dilakukan dalam 7 , 14, dan 28 hari. Limbah plastik jenis PET sendiri akan digunakan sebagai bahan pengganti agregat kasar. Variasi penggunaan plastik jenis PET terhadap berat agregat kasar adalah 5\%, 10\% dan 15\%. Jumlah sampel untuk masing-masing kondisi adalah 3 buah sampel, sehingga total sampel yang digunakan adalah sebanyak 36 buah. Nilai kuat tekan beton menurun seiring dengan penambahan kadar limbah plastik PET. Kuat tekan rata-rata untuk variasi campuran agregat kasar limbah plastik PET $0 \%$ (normal), $5 \%, 10 \%$, dan $15 \%$ berturut-turut sebesar : $272,40 \mathrm{~kg} / \mathrm{cm}^{2}$, $246,27 \mathrm{~kg} / \mathrm{cm}^{2}, 239,82 \mathrm{~kg} / \mathrm{cm}^{2}$, dan $206,31 \mathrm{~kg} / \mathrm{cm}^{2}$.
\end{abstract}

\section{Kata kunci}

Beton mutu rendah, limbah plastik PET, kuat tekan beton

\section{PENDAHULUAN}

Pekerjaan pembangunan di kota yang sedang berkembang di Indonesia seperti Palangka Raya meliputi pembangunan hotel, gedung perkantoran pemerintah, perumahan dan lain sebagainya sedang banyak dilakukan. Pekerjaan tersebut tentu memerlukan jumlah material penyusun beton yang relatif banyak dan memakan biaya relatif tinggi. Penelitian mengenai kuat tekan beton dengan menggunakan material non konvensional telah banyak dilakukan di Kota Palangka Raya. Sebagai contoh adalah pengguaan abu sekam dalam campuran beton yang sudah 
diteliti di Palangka Raya. Campuran beton dengan bahan non konvensional tersebut, tentunya harus melalui pengujian sesuai standar yang telah ditetapkan oleh Departemen Pekerjaan Umum (DPU).

Subjek dalam penelitian mengenai beton antara lain kerikil atau agregat kasar sebagai salah satu bahan penyusun beton. Dari tahun ke tahun harga kerikil semakin mahal, sehingga penelitian untuk mengurangi penggunaan kerikil pada pembuatan beton banyak dilakukan. Untuk mengurangi penggunaan kerikil sebagai bahan campuran beton, maka perlu dicari material pengganti yang lebih murah dan memenuhi syarat. Salah satu material yang patut dipertimbangkan adalah limbah plastik jenis PET (Poly Ethylene Terephthalate).

Penggunaan limbah plastik sebagai bahan campuran beton akan sangat bermanfaat dari segi ekonomi karena harganya yang jauh lebih murah dibanding agregat kasar atau kerikil. Namun manfaat besar lainnya adalah dari segi lingkungan. Menurut Pratikto ${ }^{[5]}$ racun dari plastik terlepas saat terurai atau terbakar, sehingga tidak ada satu bakteri pun yang dapat menguraikan sampah plastik. Semakin banyak penggunaan PET maka limbah dari PET juga akan semakin meningkat. Walaupun plastik jenis poliester ini tidak menimbulkan bahaya yang langsung terhadap lingkungan, yakni tidak menghasilkan bahan penyebab turunnya kualitas kesehatan manusia, namun plastik ini tidak dapat langsung didegradasi di alam ${ }^{[2]}$.

Dari kedua pendapat tersebut, dapat disimpulkan bahwa limbah plastik jenis PET merupakan jenis limbah yang bisa merusak lingkungan. Di Kota Palangka Raya sendiri, timbulan sampah yang berasal dari limbah plastik jumlahnya cukup besar. Permana dan Trihadiningrum $^{[4]}$ mengungkapkan bahwa komposisi sampah yang berasal dari limbah plastik di Kota Palangka Raya mencapai $14,95 \%$ dari keseluruhan timbulan sampah. Kesimpulan yang didapat adalah bahwa plastik menjadi penyumbang sampah terbesar kedua setelah sampah basah di Kota Palangka Raya.

Pertanyaan yang timbul adalah apakah limbah plastik jenis PET dapat memenuhi syarat sebagai bahan pembuatan beton dengan kondisi agregat di Palangka Raya. Apakah kuat tekan beton yang direncanakan akan memenuhi ketentuan bila limbah plastik jenis PET digunakan untuk pengganti kerikil. Pratikto $^{[6]}$ menyimpulkan bahwa PET dapat digunakan dalam pembuatan beton ringan dengan rasio perbandingan untuk campuran setiap $\mathrm{m}^{3}$ beton ringan adalah semen $263 \mathrm{~kg}$, pasir $420 \mathrm{~kg}$, air $279 \mathrm{~kg}$ dan agregat PET 559 $\mathrm{kg}$ pada pemakaian additive $50 \mathrm{ml}$. Setiawan [7] menyatakan bahwa limbah botol plastik jenis PET dapat dijadikan sebagai pengganti agregat kasar beton ringan dengan melalui proses pemanasan, pendinginan, dan pemecahan.

Dari penelitian yang sudah dilakukan tersebut, dapat diambil kesimpulan bahwa limbah plastik jenis PET dapat digunakan dalam pembuatan beton. Limbah plastik tersebut digunakan sebagai bahan pengganti kerikil atau agregat kasar. Namun penelitian tersebut dilakukan di luar Kota Palangka Raya dimana material agregat halus sebagai bahan pembuat beton lainnya tentu berbeda dengan yang ada di Palangka Raya. Penelitian tentang pemanfaatan limbah plastik jenis PET dalam pembuatan beton di Kota Palangka Raya tentu perlu untuk dilakukan. Berdasarkan hal tersebut, maka dilakukanlah penelitian berjudul "Pemanfaatan Limbah Plastik Jenis PET (Poly Ethylene Terephthalate) Pada Pembuatan Beton Mutu Rendah Di Kota Palangka Raya”.

Beton mutu rendah adalah beton dengan mutu di bawah K-250 Penelitian ini menggunakan Semen Portland, air bersih dari PDAM, agregat lokal dari Bukit Rawi dan Bukit Batu serta limbah plastik jenis PET yang diambil dari tempat pembuangan sampah di sekitar Kota Palangka Raya.

\section{METODE PENELITIAN Alat dan Bahan}

Alat yang digunakan dalam penelitian ini adalah:

1. Alat uji kuat tekan beton

2. Alat abrasi agregat kasar (Los Angeles Machine)

3. Oven

4. Kubus beton 
5. Alat analisis saringan

6. Alat uji berat jenis

Bahan yang digunakan dalam penelitian ini adalah:

1. Semen

2. Agregat kasar dari Tangkiling

3. Agregat halus dari Tangkiling

4. Limbah PET

5. Air

\section{Prosedur Penelitian}

\section{Persiapan Agregat Kasar Dari Limbah PET}

Tahap ini dimulai dari pembuatan agregat kasar dari limbah plastik jenis PET. Kemudian agregat kasar dari limbah tersebut dipanaskan yang selanjutnya didinginkan. Setelah itu dipecah dengan ukuran yang sudah ditentukan sehingga menjadi agregat kasar.

\section{Tahap Uji Material Penyusun Beton}

Tahapan pengujian material penyusun beton adalah sebagai berikut:

1. Menguji Kadar Air Agregat

Standar yang dipakai dalam pengujian ini adalah SNI 03-1971-2008. Tujuan dari pengujian ini adalah untuk memperoleh angka persentase dari kadar air yang dikandung oleh agregat. Material yang diuji adalah agregat halus (pasir) dan agregat kasar (batu pecah). Material berasal dari Bukit Rawi dan Bukit Batu Kota Palangka Raya.

\section{Menguji Berat Jenis Agregat Kasar}

Standar yang dipakai dalam pengujian ini adalah SNI 03-1969-2008. Tujuan dari pengujian ini adalah untuk memperoleh angka berat jenis curah, berat jenis kering permukaan dan berat jenis semu serta besarnya angka penyerapan. Material yang diuji adalah agregat kasar (dari limbah plastik jenis PET).

\section{Menguji Berat Jenis Agregat Halus}

Standar yang dipakai adalah SNI 03-19702008. Tujuan pengujian ini adalah untuk menentukan berat jenis dan penyerapan pasir pada kondisi saturated surface dry (SSD) dan pada keadaan jenuh. Material yang diuji adalah agregat halus (pasir).
4. Analisa Saringan Agregat Halus Dan Kasar Standar yang dipakai dalam pengujian ini adalah SNI 03-1968-2008. Tujuan dari pengujian ini adalah untuk memperoleh distribusi besaran atau jumlah persentase butiran baik agregat halus maupun agregat kasar. Distribusi yang diperoleh dapat ditunjukan dalam tabel atau grafik. Material yang diuji adalah agregat halus (pasir) dan agregat kasar (dari limbah plastik jenis PET).

5. Menguji Kadar Lumpur Agregat Halus Lewat Saringan No.200

Tujuan dari percobaan ini adalah untuk menentukan kadar lumpur yang terdapat dalam agregat halus lewat saringan no.200 dengan cara pencucian. Material yang diuji adalah pasir.

6. Menguji Keausan Agregat Dengan Mesin Abrasi Los Angeles

Standar yang dipakai dalam pengujian ini adalah SNI 03-2417-2008. Tujuan dari pengujian ini adalah menentukan ketahanan agregat kasar terhadap keausan yang terjadi dengan menggunakan Mesin Abrasi Los Angeles. Material yang diuji adalah agregat kasar (dari limbah plastik jenis PET).

\section{Perencanaan Rancangan Campuran Beton (Mix Design)}

Perencanaan campuran beton dilakukan untuk mengetahui komposisi yang tepat antara berat semen, berat masing-masing agregat dan berat air yang diperlukan untuk mencapai suatu kekuatan yang diinginkan. Dalam teori teknologi beton dijelaskan bahwa faktor-faktor yang sangat mempengaruhi kekuatan beton ialah (1) faktor air semen (water-cement ratio) dan kepadatan, (2) umur beton, (3) jenis semen, (4) jumlah semen dan (5) sifat agregat.

Perencanaan campuran beton dapat dilakukan dengan berbagai macam cara antara lain perancangan model Amerika berdasarkan American Concrete Institute (ACI) dan perancangan model Inggris yang berdasarkan British Standard (BS) dan dikenal dengan Metode DOE (Department of Environment). 


\section{Pembuatan Benda Uji}

Tahapan ini meliputi perencanaan adukan campuran beton, menggunakan metode campuran sesuai SNI tahun 2008 dengan judul buku Tata Cara Pembuatan Rencana Campuran Beton Normal dengan perencanaan mutu beton yang direncanakan pada umur 28 hari adalah (K-225) dengan kubus beton sebagai benda uji berukuran $15 \mathrm{~cm} \times 15 \mathrm{~cm} \times 15 \mathrm{~cm}$ berjumlah tiga sampel.

\section{Pengujian Benda Uji}

Menguji kuat tekan beton mutu K-225 dilakukan pada umur beton 7, 14 dan 28 hari menggunakan 3 sampel setiap variasinya.

1. Uji Slump

Uji ini dimaksudkan untuk mengukur nilai slump adukan beton segar sehingga dapat diketahui kemudahan untuk mengerjakan (workability).

\section{Uji Kuat Tekan}

Standar yang dipakai dalam uji ini adalah SNI 03-1974-2008. Tujuan pengujian ini adalah untuk memperoleh nilai kuat tekan dengan prosedur yang benar.

\section{HASIL DAN PEMBAHASAN}

Hasil yang didapat dari penelitian ini adalah sebagai berikut.

\section{Beton K 250 Tanpa Penambahan Limbah PET}

Kuat tekan beton K 250 sebelum ditambah limbah PET dapat dilihat pada Gambar 1 berikut

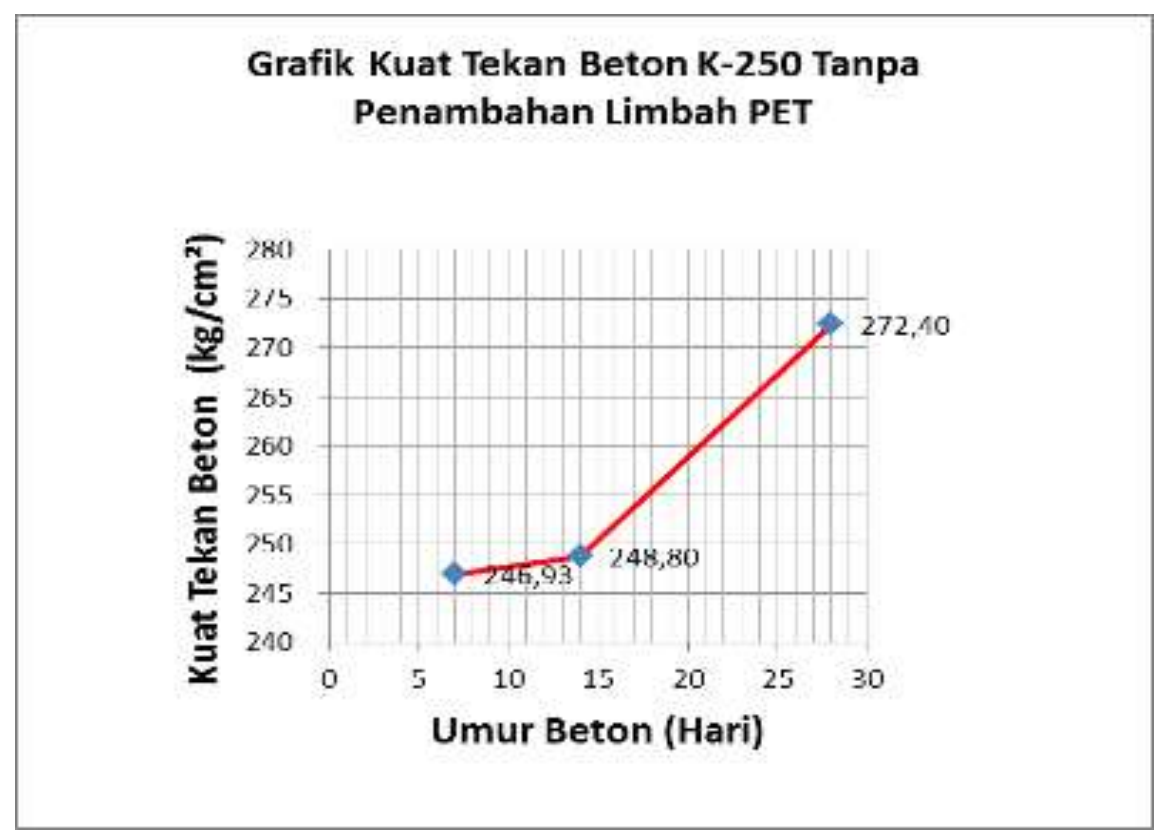

Gambar 1. Kuat tekan beton K 250 tanpa penambahan limbah PET

Pada Gambar 1 terlihat bahwa nilai kekuatan tekan beton mengalami peningkatan seiring bertambahnya umur beton. Pada grafik terlihat kuat tekan beton normal pada umur 7 hari adalah $246,93 \mathrm{~kg} / \mathrm{cm}^{2}$, dan meningkat lagi pada pengujian beton kedua umur 14 hari yaitu kuat tekan mencapai $248,80 \mathrm{~kg} / \mathrm{cm}^{2}$, dan pada pengujian ketiga di umur 28 hari kuat tekan bertambah secara perlahan hingga mencapai kuat tekan $272,40 \mathrm{~kg} / \mathrm{cm}^{2}$.

\section{Beton K 250 Dengan Penambahan Limbah PET 5\%}

Adapun kuat tekan beton K 250 setelah penambahan limbah PET sebesar 5\% dapat dilihat pada Gambar 2 berikut. 


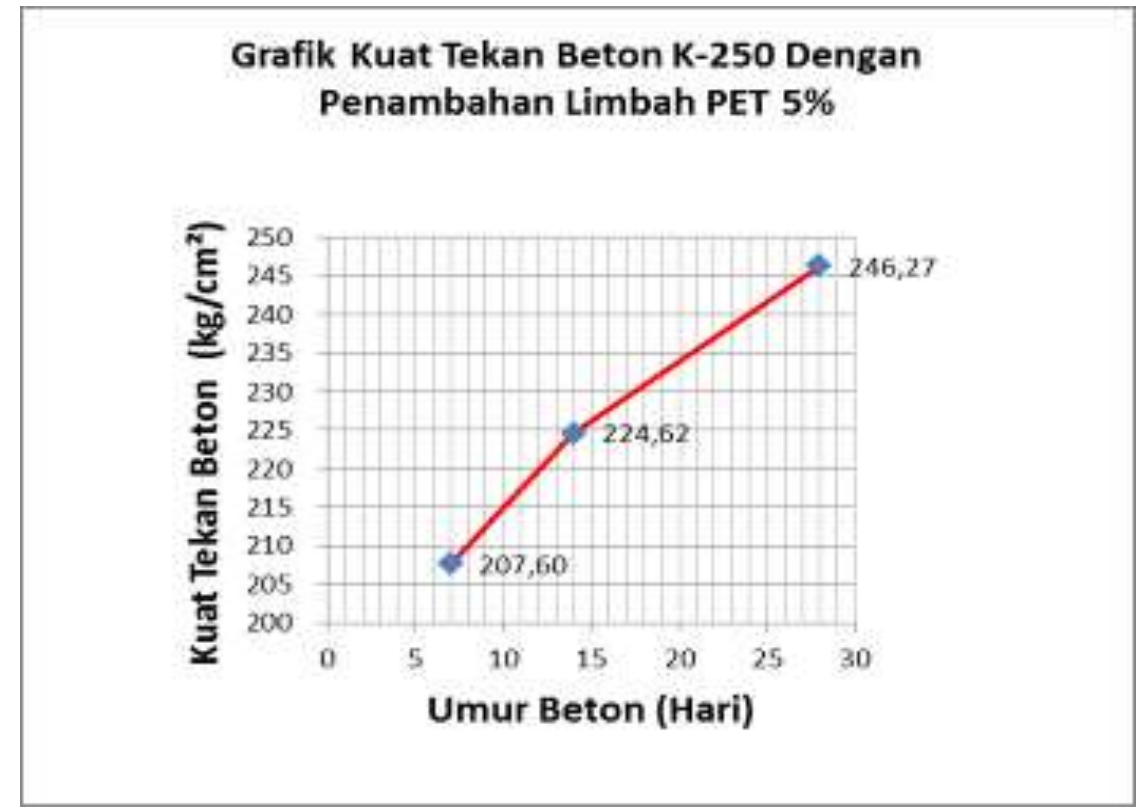

Gambar 2. Kuat tekan beton K 250 dengan penambahan limbah PET 5\%

Pada Gambar 2 terlihat nilai kekuatan tekan beton mengalami peningkatan seiring bertambahnya umur beton. Kuat tekan beton pada umur 7 hari adalah 207,60 $\mathrm{kg} / \mathrm{cm}^{2}$, meningkat pada umur 14 hari yaitu mencapai $224,62 \mathrm{~kg} / \mathrm{cm}^{2}$, dan pada pengujian ketiga di umur 28 hari kuat tekan bertambah signifikan mencapai kuat tekan $246,27 \mathrm{~kg} / \mathrm{cm}^{2}$.

\section{Beton K 250 Dengan Penambahan Limbah PET 10\%}

Adapun kuat tekan beton K 250 setelah penambahan limbah PET sebesar 10\% dapat dilihat pada Gambar 3 berikut.

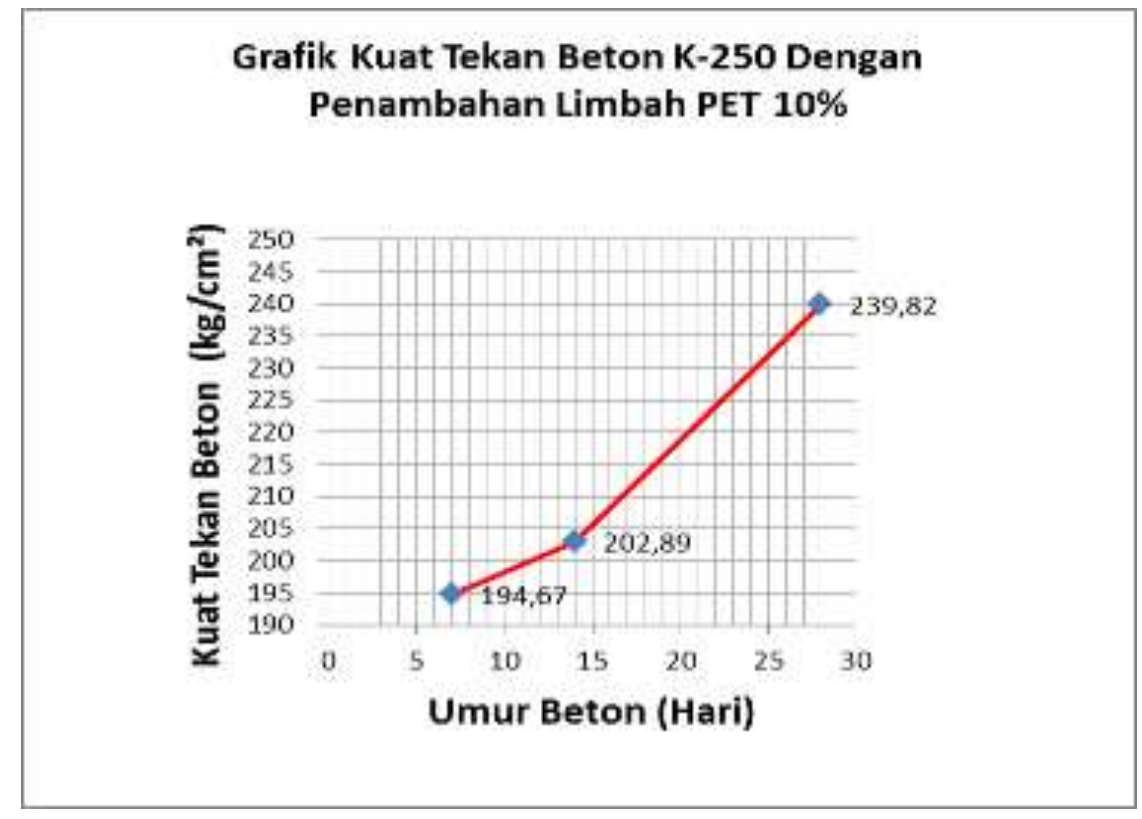

Gambar 3. Kuat Tekan Beton K 250 Dengan Penambahan Limbah PET 10\%

Pada Gambar 3 terlihat bahwa nilai kekuatan tekan beton mengalami peningkatan seiring bertambahnya umur beton. Pada grafik terlihat kuat tekan beton pada umur 7 hari 
adalah 194,67 kg/cm², dan meningkat lagi pada pengujian beton kedua umur 14 hari yaitu kuat tekan mencapai $202,89 \mathrm{~kg} / \mathrm{cm}^{2}$, dan pada pengujian ketiga di umur 28 hari kuat tekan bertambah secara signifikan hingga mencapai kuat tekan $239,82 \mathrm{~kg} / \mathrm{cm}^{2}$.
Beton K 250 Dengan Penambahan Limbah PET 15\%

Adapun kuat tekan beton K 250 setelah penambahan limbah PET sebesar $10 \%$ dapat dilihat pada Gambar.4 berikut.

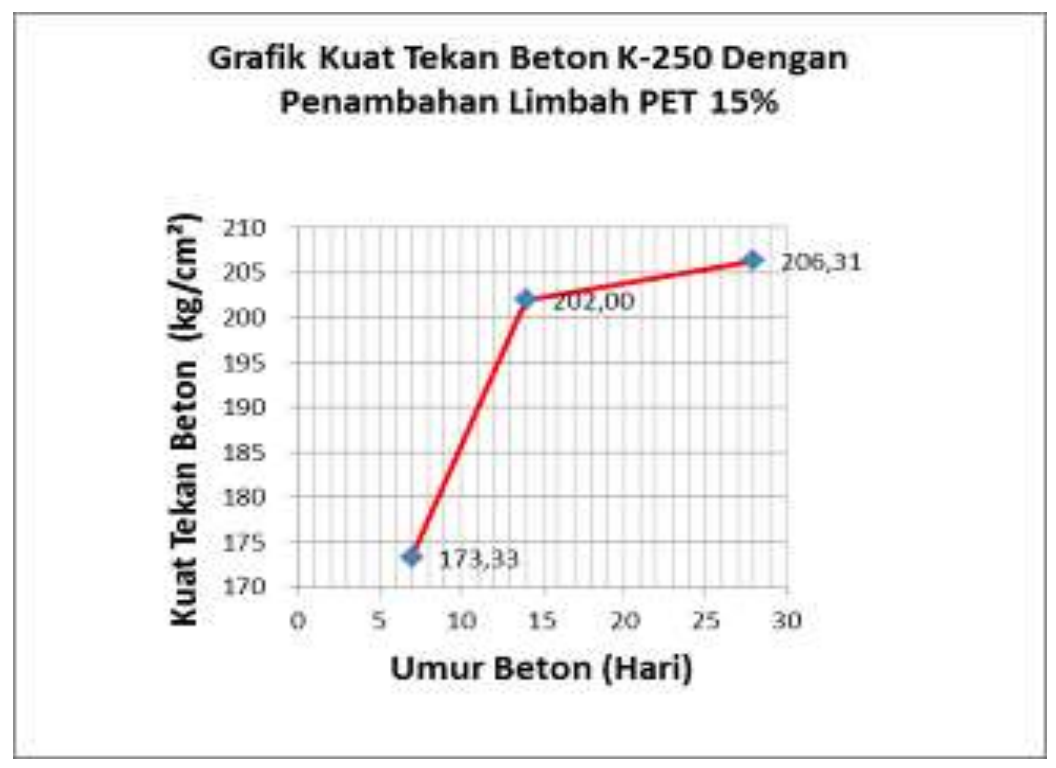

Gambar 4. Kuat Tekan Beton K 250 Dengan Penambahan Limbah PET 15\%

Pada Gambar 4 terlihat nilai kekuatan tekan beton mengalami peningkatan seiring bertambahnya umur beton. Kuat tekan beton pada umur 7 hari adalah $173,33 \mathrm{~kg} / \mathrm{cm}^{2}$, dan meningkat secara signifikan pada pengujian beton kedua umur 14 hari yaitu kuat tekan mencapai $202,00 \mathrm{~kg} / \mathrm{cm}^{2}$, dan pada pengujian ketiga di umur 28 hari kuat tekan bertambah sedikit hingga mencapai kuat tekan 206,31 $\mathrm{kg} / \mathrm{cm}^{2}$.

\section{Kuat Tekan Beton $K 250$ Tanpa Dan Dengan Penambahan Limbah PET}

Adapun kuat tekan beton K 250 secara keseluruhan dapat dilihat pada Gambar 5 berikut.

\section{Grafik Kuat Tekan Beton K-250 Dengan Berbagai Variasi Penambahan \\ Limbah PET}

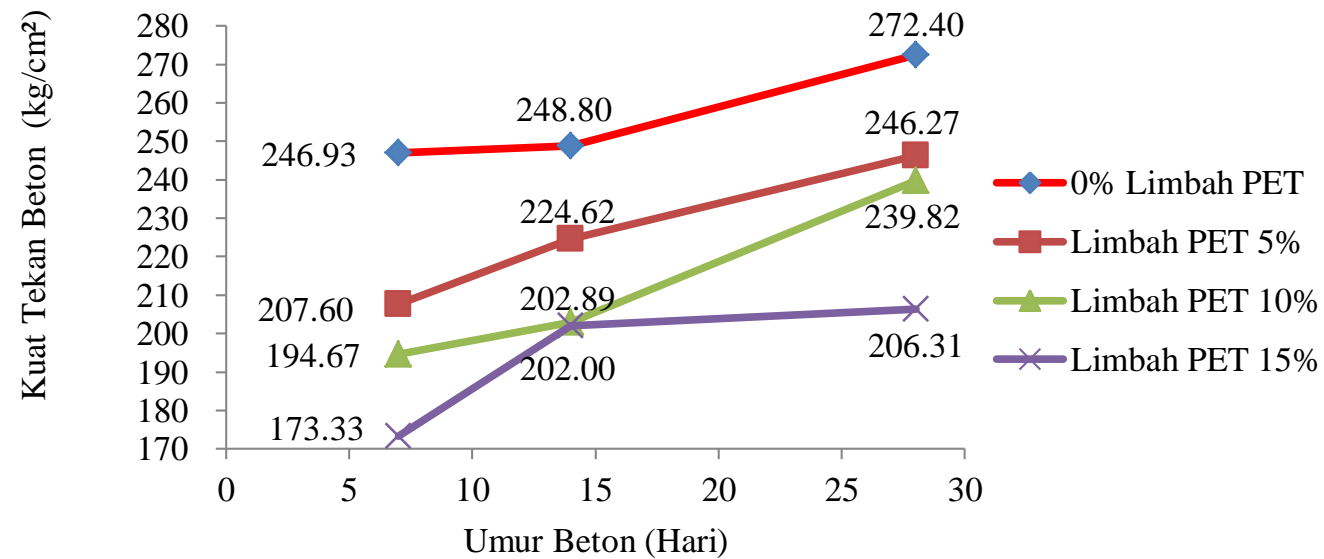

Gambar 5. Grafik Kuat Tekan Beton K 250 Dengan Variasi Penambahan Limbah PET 
Pada Gambar 5 terlihat bahwa nilai kuat tekan beton menurun seiring dengan penambahan kadar limbah plastik PET. Kuat tekan rata-rata untuk variasi campuran agregat kasar limbah plastik PET 0\% (normal), 5\%, $10 \%$, dan $15 \%$ berturut-turut sebesar 272,40 $\mathrm{kg} / \mathrm{cm}^{2}, \quad 246,27 \mathrm{~kg} / \mathrm{cm}^{2}, 239,82 \mathrm{~kg} / \mathrm{cm}^{2}$, dan $206,31 \mathrm{~kg} / \mathrm{cm}^{2}$. Dari sini bisa disimpulkan bahwa penambahan limbah plastik PET disarankan tidak melebihi $5 \%$ dari berat agregat kasar.

\section{KESIMPULAN}

Berdasarkan hasil penelitian, maka dapat diberi kesimpulan sebagai berikut.

1. Kuat tekan beton maksimum tanpa limbah PET adalah $272,40 \mathrm{~kg} / \mathrm{cm}^{2}$ pada umur 28 hari.

2. Penambahan limbah PET 5\% diperoleh kuat tekan beton maksimum adalah 246,27 $\mathrm{kg} / \mathrm{cm}^{2}$ pada umur 28 hari.

3. Penambahan limbah PET $10 \%$ diperoleh kuat tekan beton maksimum adalah 239, 82 $\mathrm{kg} / \mathrm{cm}^{2}$ pada umur 28 hari

4. Penambahan limbah PET 15\% diperoleh kuat tekan maksimum adalah 206,31 $\mathrm{kg} / \mathrm{cm}^{2}$ pada umur 28 hari

5. Penambahan limbah PET efektif dilakukan sebesar 5\% dari berat agregat kasar.

\section{SARAN}

Berdasarkan kesimpulan hasil penelitian ini, maka saran yang bisa diberikan adalah sebagai berikut.

1. Pemakaian limbah PET tidak melebihi 5\% dari berat agregat kasar.

2. Perlu dilakukan penelitian lanjutan untuk melihat kuat tekan beton bila seluruh agregat kasar diganti dengan limbah PET.

\section{REFERENSI}

[1] Direktorat Jenderal Bina Marga. Kementerian Pekerjaan Umum. 2010. Spesifikasi Umum. Revisi 2. Jakarta: Direktorat Jenderal Bina Marga.

[2] Mahmudah, S., Rosidatul, Atmaja, L., 2012, Pengaruh Konsentrasi Katalis Kalium Karbonat Pada Proses Depolimerisasi Limbah Botol Plastik Polietilen Tereftalat (PET), Jurnal Sains dan Seni, 1(1).
[3] Badan Standar Nasional, 2000, Tata Cara Pembuatan Rencana Campuran Beton Normal, Jakarta, Badan Standardisasi Nasional.

[4] Permana, T. J., Trihadiningrum, Y., 2015, Kajian Pengadaan Dan Penerapan Tempat Pengolahan Sampah Terpadu (TPST) Di TPA Km.14 Kota Palangka Raya, Prosiding Seminar Nasional Manajemen Teknologi XI, Surabaya: Program Studi MMT-ITS.

[5] Pratikto, 2010, Beton Ringan BerAgregat Limbah Botol Plastik Jenis PET (Poly Ethylene Terephthalate), Poli Teknologi, 9 (1), 1-8.

[6] — , 2011, Pemanfaatan Superplasticizer Pada Beton Ringan Struktural Beragregat Limbah Botol Plastik Jenis PET (Poly Ethylene Terephthalate), Poli Teknologi, 10 (1).

[7] Setiawan, H., 2015, Pemanfaatan Limbah Botol Plastik Jenis PET (Poly Ethylene Terephthalate) Sebagai Material Agregat Kasar Beton Ringan Yang Ramah Lingkungan, Universitas Lambung Mangkurat.

[8] Standard Nasional Indonesia, 2008, Tata Cara Campuran Beton Normal, Bandung, Pustajatan-Balitbang Pekerjaan Umum. 